\title{
Overview of genetic and epigenetic alterations in the pathogenesis of esophagogastric junctional adenocarcinoma and esophageal adenocarcinoma: recent findings by next generation sequencing
}

\author{
Yu Imamura ${ }^{1,2}$, Ryuma Tokunaga ${ }^{2}$, Kenichi Nakamura², Hideo Baba², Masayuki Watanabe ${ }^{1,2}$ \\ ${ }^{I}$ Department of Gastroenterological Surgery, Cancer Institute Hospital of Japanese Foundation for Cancer Research, Tokyo 135-8550, Japan. \\ ${ }^{2}$ Department of Gastroenterological Surgery, Graduate School of Medical Sciences, Kumamoto University, Kumamoto 860-8555, Japan.
}

Correspondence to: Dr. Yu Imamura, Department of Gastroenterological Surgery, Cancer Institute Hospital of Japanese Foundation for Cancer Research, 3-8-31 Ariake, Koto, Tokyo 135-8550, Japan. E-mail: yu.imamura@jfcr.or.jp

\section{A B S T R A C T}

Esophagogastric junctional adenocarcinoma is commonly treated as esophageal adenocarcinoma (EAC) and has dramatically increased in Western countries for several decades. The similar trend has been observed in Asian countries (not in China). Barrett's esophagus (BE) is a widely accepted precursor of EAC. Recent advances of next-generation sequencing could provide researchers with a better understanding of genetic and epigenetic alterations in the carcinogenesis of EAC. In this review, we have summarized the recently reported major genetic and epigenetic alterations in both BE and EAC. Sonic hedgehog/bone morphogenetic protein axis, which is a key signaling for esophageal development, plays an important role in BE intestinal metaplasia. Single nucleotide polymorphisms related to esophageal organogenesis, such as FOXF1 and FOXP3, are frequently detected in BE patients. During the progression of BE to adenocarcinoma, lacking of normal function of TP53 and CDKN2A by loss of heterozygosity (LOH), mutation, or promoter methylation has been frequently observed. $\mathrm{LOH}$ at $9 \mathrm{p}$ (coding CDKN2A) is an earlier event to EAC carcinogenesis compared to that at 17q (coding TP53) LOH. In order to further elucidate the pathogenesis of BE and EAC, it will be necessary to analyze these genetic/epigenetic alterations in combination with clinical data in a large-scale cohort.

Key words: Barrett's esophagus, carcinogenesis, epigenetic, esophageal adenocarcinoma, esophagogastric junctional adenocarcinoma, genetic, intestinal metaplasia

\section{Introduction}

Esophagogastric junctional (EGJ) adenocarcinoma is classified as I to III, based on the location of the tumor center or tumor mass, by Rudiger Siewert et al. ${ }^{[1]}$ EGJ cancer is considered to be an esophageal cancer, according to the 7th edition of Union for International Cancer Control tumour, node, metastasis classification. ${ }^{[2]}$ EGJ adenocarcinoma/esophageal adenocarcinoma (EAC) has dramatically increased by $600 \%$, mainly in Western countries, over the past few decades, although the current incidence rate shows only a moderate increase. ${ }^{[3]}$ Currently, a similar trend was reported in Asian country. ${ }^{[4]}$ EGJ adenocarcinoma often presents at a late stages despite recent improvements in diagnostic technology and multidisciplinary treatment. The 5-year survival rate is reported to be about $20 \%$ and median survival less than one year. ${ }^{[3,5]}$

Barrett's esophagus (BE) is a widely accepted precursor of EGJ adenocarcinoma/EAC, although the reported risk

\section{Access this article online}

Quick Response Code:

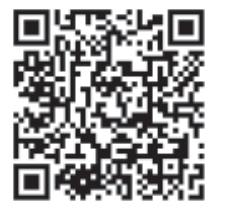

Website:

www.jcmtjournal.com

DOI:

$10.4103 / 2394-4722.161620$ is around $0.5 \%$ per year. ${ }^{[6]}$ Epidemiological studies have revealed that adenocarcinomas occur from BE through multistep morphological changes, such as low-grade to high-grade dysplasia. ${ }^{[6,7]} \mathrm{BE}$ and EGJ adenocarcinoma/ EAC share poly-genetic/epigenetic alterations. ${ }^{[8]} \mathrm{BE}$ can be described as mucosal replacement of normal squamous epithelium with metaplastic columnar mucosa, known as specialized columnar metaplasia, in response to chronic gastroesophageal reflux disease (GERD). ${ }^{[9]}$ Understanding the pathogenesis of $\mathrm{BE}$ and EGJ adenocarcinoma/EAC is important in prevention and thus the development of molecular targeting therapy. Here, we review the pathogenesis of EGJ adenocarcinoma/EAC, including $\mathrm{BE}$, focusing on molecular alterations. We use the term EAC and include EGJ adenocarcinoma.

This is an open access article distributed under the terms of the Creative Commons Attribution-NonCommercial-ShareAlike 3.0 License, which allows others to remix, tweak, and build upon the work non-commercially, as long as the author is credited and the new creations are licensed under the identical terms.

For reprints contact: reprints @ medknow.com

How to cite this article: Imamura $\mathrm{Y}$, Tokunaga $\mathrm{R}$, Nakamura $\mathrm{K}$, Baba $\mathrm{H}$, Watanabe $\mathrm{M}$. Overview of genetic and epigenetic alterations in the pathogenesis of esophagogastric junctional adenocarcinoma and esophageal adenocarcinoma: recent findings by next generation sequencing. J Cancer Metastasis Treat 2015;1:123-9

Received: 09-06-2015; Accepted: 26-06-2015. 


\section{Barrett's Esophagus}

$\mathrm{BE}$ is defined by American Gastroenterological Association as "BE is the condition in which any extent of metaplastic columnar epithelium that predisposes to cancer development replaces the stratified squamous epithelium that normally lines the distal esophagus."[10] This means a specialized columnar epithelium characterized by columnar cells, goblet cells, and a villous-like structure. ${ }^{[11,12]}$ However, another classification includes two types of BE. One is "junctional or cardiac type," consisting of the predominantly foveolar surface containing mucous glands and resembling cardiac mucous glands. Another one is "gastric-fundic type," containing both parietal and chief cells with atrophic fundic glands. ${ }^{[1-13]}$ Thus, the histological definition of BE remains controversial.

The cell of origin of BE has not yet been elucidated. Six cell types are currently considered as potential origins, including transdifferentiation of esophageal squamous cells, ${ }^{[14]}$ gastric cardia cells, ${ }^{[15]}$ esophageal submucosal gland cells, ${ }^{[16]}$ esophageal progenitor cells, ${ }^{[17]}$ circulating bone marrow cells, ${ }^{[18]}$ and residual embryonic cells at squamo-columunar junction (SCJ). ${ }^{[19]}$

There are some reports suggesting an association between p63 and intestinal metaplasia. p63 null embryos have idiopathic metaplasia in SCJ. ${ }^{[20]}$ It has been shown that genetic alterations in metaplastic cells in mice lacking p63 were similar to those in human BE. ${ }^{[21]}$ It has also been suggested that epithelium with such genetic changes may originally exist at SCJ. Also, lack of SRY (sex determining region $\mathrm{Y}$ ) box 2 (SOX2) induces columnar changes in esophageal epithelium in mice models. ${ }^{[22]}$ Both p63 and SOX2 are essential for squamous epithelial formation during organogenesis. Although these findings were based on studies using rodent esophagus, there are structural differences in the esophageal between rodents and human. For example, in rodents, the esophagus lacks submucosal glands and SCJ is located in mid-stomach. Therefore, findings in rodent models may not be applicable to human BE.

\section{Molecular and Genetic Alterations Related to Intestinal Metaplasia and Intestinal Differentiation}

Sonic hedgehog (SHH)/bone morphogenetic protein (BMP) signaling plays an important role in the development of columnar metaplasia, being associated with organogenesis, especially of the esophageal. These are critical molecules for separating trachea from the esophagus $^{[23]}$ and are involved in the development of cell-renewable epithelium. ${ }^{[24]}$ Expressions of SHH and BMP4 are usually low in human squamous epithelia. In BE tissue, however, SHH/BMP4 signaling induces SRY (sex determining region Y) box 9 (SOX9). ${ }^{[25,26]}$ SOX9 subsequently induces CDX2 and MUC2 expression, which are related to an intestinal phenotype. ${ }^{[27]}$ Furthermore, BMP4 shifts the gene expression profile of normal squamous cells into columnar cells. Because cytokeratin $(\mathrm{CK})$ is a major cytoskeleton molecule, it can be regarded as a representative phenotype of certain cells. CK 13/14 expressions are highly expressed in squamous cells, whereas $\mathrm{CK} 7,8,18$, and 20 expressions elevated in BE epithelium. ${ }^{[28]}$ It has been shown that expression of SOX9, but not CDX2 or BMP4, induces squamous epithelial cells formation toward columnar-like epithelium with expression of CK 8. ${ }^{[29]} \mathrm{SHH} / \mathrm{BMP}$ signaling were also activated in a mouse model with interleukin- $1 \beta$ overexpression. After one year of continuous inflammation, intestinal metaplasia occurred at the SCJ, and the gene expression pattern of those metaplastic cells was similar to those in human BE. ${ }^{[30]}$

Recent advances of next-generation sequencing have provided the opportunity to elucidate genetic alterations such as single nucleotide polymorphisms (SNPs). The association between SNPs and BE has been clarified. It has been reported that chromosomes 2p24 (rs3072), 12q24 (rs2701108), 6p21 (rs9257809), and 16q24 (rs9936833) are related to risk of BE development. ${ }^{[11,32]}$ Among these SNPs, rs9936833 at $16 \mathrm{q} 24$ is located close to FOXF1, which is a transcription factor in the SHH signaling pathway. Interestingly, FOXF1 is associated with embryonic development of gastrointestinal tract formation, especially the esophagus. ${ }^{[33]}$ Also, the importance of FOXP3, at $3 p 14$ (rs2687201), which is also known to possess a role in esophageal organogenesis, is based on analyzing datasets of BE or EAC cases. ${ }^{[34]} 19 \mathrm{p} 13$ (rs10419226) and 9p22 (rs11789015), with significant relation to BE and EAC, has also been identified. rs10419226 SNPs at 19p13 are known as an intronic variant of cAMP-regulated transcriptional co-activators (CRTC1). CRTC signaling exerts oncogenic activities when activated by loss of LKB1 through transcriptional activation of LYPD3, which contributes to esophageal tumor progression. ${ }^{[35]}$ rs11789015 SNP at 9p22 is located at the intron region of $B A R X 1$. BARX1 is a transcription factor involved in tracheal and foregut organogenesis in developing mouse embryos. ${ }^{[36,37]}$ These findings suggest that key molecules in BE development may overlap with those in esophageal development.

Wnt/ $\beta$-catenin, and Notch are critical signaling for intestinal differentiation. Wnt family is one of the fundamental mechanisms of cell proliferation, polarity, and differentiation. ${ }^{[38]}$ Wnt signaling pathways include $\mathrm{Wnt} / \beta$-catenin canonical pathway and $\mathrm{Wnt} /$ calcium or Wnt/planar cell polarity non-canonical pathway. Among these, Wnt/ $\beta$-catenin pathway is associated with intestinal type gene expressions. ${ }^{[39,40]}$ Wnt signaling also regulates $C D X$ gene expression, which controls intestinal differentiation, and homeostasis. ${ }^{[1]}$ Notch signaling 
also plays an important role in intestinal differentiation in cell proliferation, apoptosis, and normal cell differentiation. ${ }^{[42,43]}$

SHH, BMP4, SOX9, and CDX2 are key molecules for the development of intestinal metaplasia. $\mathrm{SHH} /$ BMP4 axis, which is a key signaling for esophageal development, plays an important role in the intestinal metaplasia of BE. In addition, SNPs that are related to esophageal organogenesis, such as FOXF1 and FOXP3, are frequently observed in BE patients [Table 1].

\section{Genetic Alterations in Progression of $\mathrm{BE}$ to EAC}

Few cases of BE will develop high-grade dysplasia or adenocarcinoma. The widely accepted molecular events during progression of $\mathrm{BE}$ to adenocarcinoma are loss of normal TP53 and CDKN2A function. Mechanisms underlying this have been explained by loss of heterozygosity $(\mathrm{LOH})$, mutation, or promoter methylation. Tumor suppressor genes, TP53 and CDKN2A, are located at $17 \mathrm{p}$ and $9 \mathrm{p}$, respectively. ${ }^{[4]} 17 \mathrm{p} \mathrm{LOH}$ occurs frequently in EAC, ${ }^{[45-47]}$ while TP53 mutation possesses malignant transformation potential during EAC carcinogenesis. ${ }^{[48]} 9 p$ $\mathrm{LOH}$ has been reported to be the important factor driving to EAC. ${ }^{[44]}$ Somatic mutation of $C D K N 2 A$ has also been detected in EAC cases. ${ }^{[49]}$ In addition, tumors harboring promoter methylation in $C D K N 2 A$ showed a higher risk of EAC progression. ${ }^{[50,51]}$ Although 9p LOH is an earlier event during EAC carcinogenesis compared to $17 \mathrm{q} \mathrm{LOH}$, patients with BE harboring 9p LOH experienced much higher incidence of EAC compared to those with $17 \mathrm{q} \mathrm{LOH}^{[44]}$

Comprehensive genetic analysis has provided new insights in the genetic landscape of BE-to-EAC. One group has shown that most mutations in EAC had already occurred in matched BE, using comprehensive genetic analysis on 11 cases with EAC and 2 of BE. Another group analyzed the mutations in selected 26 genes and reported that around half of the cases with $\mathrm{BE}$ without dysplasia already possessed mutations. Also, there was no significant difference in frequencies of those mutations between BE without dysplasia, BE with high-grade dysplasia, and EAC. ${ }^{[52]}$ Of note, they also examined associations between frequencies of mutations in the 26 genes and disease stage. They also found that only TP53 and SMAD4 mutations significantly increased

Table 1: Major molecular alterations reported across malignant progression of $\mathrm{BE}$

\begin{tabular}{ll}
\hline Morphological status & Key molecular alterations \\
\hline BE & SHH, BMP4, SOX9 and CDX3 \\
Esophageal adenocarcinoma & $\begin{array}{l}\text { Loss of function of CDKN2A or } \\
\text { TP53 (by loss of heterozygosity, } \\
\text { or mutation); ARID1A, SMAD4 }\end{array}$ \\
\hline
\end{tabular}

SHH: Sonic hedgehog; BE: Barrett's esophagus; BMP: Bone morphogenetic protein; SOX9: SRY (sex determining region $\mathrm{Y}$ ) box 9 with progression of $\mathrm{BE}$ to high-grade dysplasia or EAC.

$A R I D 1 A$ is another key molecule driving BE to EAC. ${ }^{[53]}$ $A R I D 1 A$ is a member of SWI/SNF family of chromatin remodeling. This molecule has been examined mainly in gastric cancer and reported to be associated with microsatellite instability. ${ }^{[54,55]}$ ARID1A mutation was detected around $15 \%$ of $\mathrm{BE}$ with high-grade dysplasia and EAC. The frequency of loss of ARID1A by immunohistochemistry correlated with disease progression from BE to EAC. The EAC cell line, OE33, showed phenotypes of increased proliferation and aggressive invasion, as the gastric cancer cell line also did. ${ }^{[53,54]}$ In addition to $A R I D 1 A$, the other members of chromatin remodeling factors encoding genes, ARID2, and $S M A R C 4 A$ mutations, were also reported. ${ }^{[56]}$

Rho family GTPase activation is an important molecule in gastric cancer and EAC. Rho family consists of Cdc2, Rac1, and RhoA. These molecules are master regulators of actin cytoskeleton rearrangements, promote cancer cell invasion, and cell survival. In gastric cancer, a mutation of RhoA is frequently associated with diffuse-type gastric cancer. It has been reported that mutations in ELMO1 and DOCK2 are frequently noted in cases with EAC. These are intracellular mediators of RAC1. ELMO1 and DOCK2 promote tumor cell invasion and seem to be associated with EAC carcinogenesis. ${ }^{[57]}$ It was observed that $6 \%$ of EAC cases analyzed had mutations in ELMO1 and $13 \%$ in DOCK2. Other genes encoding Rac1 activating enzymes were ECT2 (1\%), TIAM1 (3\%), TRIO (3\%) and $V A V 2(1 \%)$ although these frequencies were lower than those in ELMO1 and DOCK2. Taken together, around $30 \%$ of Racl- activating mutations occurred in EAC patients. Also reported in EAC were frequent transversions of $A$ to $C$ at AA sites ( $T$ to $G$ at TT sites). ${ }^{[56,58]}$ One possible explanation was that low $\mathrm{pH}$ due to GERD induces $8-\mathrm{OH}-\mathrm{dG}$, resulting in $\mathrm{A}$ to $\mathrm{C}$ transversion at AA sites. ${ }^{[59,60]}$ Further studies also needed to clarify this interesting finding.

\section{Epigenetic Changes and microRNA Status in BE and EAC}

Recent global methylation profiling revealed that broad epigenetic alterations occur in both $\mathrm{BE}$ and $\mathrm{EAC}$ and are associated with carcinogenesis in EAC. ${ }^{[61-64]} \mathrm{CpG}$ island promoter hypermethylations are a common feature of cancer, and regulate (traditionally down-regulate) downstream gene expression. On the other hand, DNA hypomethylation increases gene expression. ${ }^{[62]}$ As for specific $\mathrm{CpG}$ island promoter methylations, $C D K N 2 A$, $A P C, \quad C D H 1, \quad M G M T, \quad T I M P-3$ and ESRl have been evaluated in several reports. ${ }^{[51,65-68]}$ CDKN2A hypermethylation has been considered to occur in early steps in EAC carcinogenesis. One study suggested that 4 genes, SLC22A18, PIGR, GJA12 and RIN2, were highly methylated in EAC compared to BE. ${ }^{[63]}$ 
Micro RNA (miRNA) is a small non-coding RNA related to post-transcriptional gene expression and silencing. Generally, up-regulation of oncogenic-miRNA or down-regulation of tumor-suppressor miRNA is identified as tumor-related miRNAs. Mir-21 up-regulation has been observed in $\mathrm{BE}$ and EAC compared with normal squamous cell epithelium and was associated with carcinogenesis. ${ }^{[69]}$ miRNA-194 was also induced in BE and $\mathrm{EAC}$ and found to be related to intestinal metaplasia and metastasis. ${ }^{[0,71]}$ miRNA-143, which suppresses transcription of $K R A S$, was down-regulated in EAC and associated with TP53. ${ }^{[72,73]}$ miRNA-31 and miRNA-375 were found to be down-regulated in EAC and are early and late-stage markers of EAC carcinogenesis. ${ }^{[74]}$

\section{Conclusion}

Recent advances of next-generation sequencing have provided researchers with better understanding of genetic and epigenetic alterations in EAC carcinogenesis. However, little study has examined those genetic and epigenetic alterations in combination with clinicopathological factors. In order to elucidate the pathogenesis of $\mathrm{BE}$ and $\mathrm{EAC}$ and to find molecules for biomarkers and targeting therapy, it will be necessary to analyze those genetic alterations in combination with clinical data in a large-scale cohort.

\section{Financial support and sponsorship}

Nil.

\section{Conflicts of interest}

There are no conflicts of interest.

\section{References}

1. Rudiger Siewert J, Feith M, Werner M, Stein HJ. Adenocarcinoma of the esophagogastric junction: results of surgical therapy based on anatomical/topographic classification in 1,002 consecutive patients. Ann Surg 2000;232:353-61.

2. Sobin L, Gospodarowicz M, Wittekind C. International union against cancer. TNM Classification of Malignant Tumours. 7th ed. Chichester, NJ: Wiley; 2010.

3. Hur C, Miller M, Kong CY, Dowling EC, Nattinger KJ, Dunn M, Feuer EJ. Trends in esophageal adenocarcinoma incidence and mortality. Cancer 2013;119:1149-58.

4. Kusano C, Gotoda T, Khor CJ, Katai H, Kato H, Taniguchi H, Shimoda T. Changing trends in the proportion of adenocarcinoma of the esophagogastric junction in a large tertiary referral center in Japan. J Gastroenterol Hepatol 2008;23:1662-5.

5. Rubenstein JH, Shaheen NJ. Epidemiology, diagnosis, and management of esophageal adenocarcinoma. Gastroenterology 2015; doi: 10.1053/j.gastro.2015.04.053.

6. Spechler SJ. Barrett esophagus and risk of esophageal cancer: a clinical review. JAMA 2013;310:627-36.

7. Chandra S, Gorospe EC, Leggett CL, Wang KK. Barrett's esophagus in 2012: updates in pathogenesis, treatment, and surveillance. Curr Gastroenterol Rep 2013;15:322.

8. Ek WE, Levine DM, D'Amato M, Pedersen NL, Magnusson PK, Bresso F, Onstad LE, Schmidt PT, Tornblom H, Nordenstedt H, Romero Y, Mayo Clinic
Esophageal A, Barrett's Esophagus Registry C, Chow WH, Murray LJ, Gammon MD, Liu G, Bernstein L, Casson AG, Risch HA, Shaheen NJ, Bird NC, Reid BJ, Corley DA, Hardie LJ, Ye W, Wu AH, Zucchelli M, Spector TD, Hysi P, Vaughan TL, Whiteman DC, MacGregor S, investigators Bs. Germline genetic contributions to risk for esophageal adenocarcinoma, Barrett's esophagus, and gastroesophageal reflux. J Natl Cancer Inst 2013;105:1711-8.

9. Flejou JF. Barrett's oesophagus: from metaplasia to dysplasia and cancer. Gut 2005;54 Suppl 1:i6-12.

10. American Gastroenterological A, Spechler SJ, Sharma P, Souza RF, Inadomi JM, Shaheen NJ. American gastroenterological association medical position statement on the management of Barrett's esophagus. Gastroenterology 2011;140:1084-91.

11. Spechler SJ, Goyal RK. Barrett's esophagus. $N$ Engl J Med 1986;315:362-71.

12. Paull A, Trier JS, Dalton MD, Camp RC, Loeb P, Goyal RK. The histologic spectrum of Barrett's esophagus. $N$ Engl J Med 1976;295:476-80.

13. Thompson JJ, Zinsser KR, Enterline HT. Barrett's metaplasia and adenocarcinoma of the esophagus and gastroesophageal junction. Hum Pathol 1983;14:42-61.

14. Chang CL, Lao-Sirieix P, Save V, De la Cueva Mendez G, Laskey R, Fitzgerald RC. Retinoic acid-induced glandular differentiation of the oesophagus. Gut 2007;56:906-17.

15. Bellin C, de Wiza DH, Wiernsperger NF, Rosen P. Generation of reactive oxygen species by endothelial and smooth muscle cells: influence of hyperglycemia and metformin. Horm Metab Res 2006;38:732-9.

16. Marchetti M, Caliot E, Pringault E. Chronic acid exposure leads to activation of the cdx2 intestinal homeobox gene in a long-term culture of mouse esophageal keratinocytes. $J$ Cell Sci 2003;116:1429-36.

17. Kong J, Nakagawa H, Isariyawongse BK, Funakoshi $\mathrm{S}$, Silberg DG, Rustgi AK, Lynch JP. Induction of intestinalization in human esophageal keratinocytes is a multistep process. Carcinogenesis 2009;30:122-30.

18. Kalabis J, Wong GS, Vega ME, Natsuizaka M, Robertson ES, Herlyn M, Nakagawa H, Rustgi AK. Isolation and characterization of mouse and human esophageal epithelial cells in 3D organotypic culture. Nat Protoc 2012;7:235-46.

19. Boch JA, Shields HM, Antonioli DA, Zwas F, Sawhney RA, Trier JS. Distribution of cytokeratin markers in Barrett's specialized columnar epithelium. Gastroenterology 1997;112:760-5.

20. Daniely Y, Liao G, Dixon D, Linnoila RI, Lori A, Randell SH, Oren M, Jetten AM. Critical role of p63 in the development of a normal esophageal and tracheobronchial epithelium. Am J Physiol Cell Physiol 2004;287:C171-81.

21. Wang X, Ouyang H, Yamamoto Y, Kumar PA, Wei TS, Dagher R, Vincent M, Lu X, Bellizzi AM, Ho KY, Crum CP, Xian W, McKeon F. Residual embryonic cells as precursors of a Barrett's-like metaplasia. Cell 2011;145:1023-35.

22. Que J, Luo X, Schwartz RJ, Hogan BL. Multiple roles for Sox2 in the developing and adult mouse trachea. Development 2009;136:1899-907.

23. Jacobs IJ, Ku WY, Que J. Genetic and cellular mechanisms regulating anterior foregut and esophageal development. Dev Biol 2012;369:54-64.

24. Ishizuya-Oka A, Hasebe T. Sonic hedgehog and bone morphogenetic protein-4 signaling pathway involved in epithelial cell renewal along the radial axis of the intestine. Digestion 2008;77 Suppl 1:42-7.

25. Mari L, Milano F, Parikh K, Straub D, Everts V, Hoeben KK, 
Fockens P, Buttar NS, Krishnadath KK. A pSMAD/CDX2 complex is essential for the intestinalization of epithelial metaplasia. Cell Rep 2014;7:1197-210.

26. Wang DH, Clemons NJ, Miyashita T, Dupuy AJ, Zhang W, Szczepny A, Corcoran-Schwartz IM, Wilburn DL, Montgomery EA, Wang JS, Jenkins NA, Copeland NA, Harmon JW, Phillips WA, Watkins DN. Aberrant epithelial-mesenchymal hedgehog signaling characterizes Barrett's metaplasia. Gastroenterology 2010;138:1810-22.

27. Zhang X, Westerhoff M, Hart J. Expression of SOX9 and CDX2 in nongoblet columnar-lined esophagus predicts the detection of Barrett's esophagus during follow-up. Mod Pathol 2015;28:654-61.

28. Van Dop WA, Rosekrans SL, Uhmann A, Jaks V, Offerhaus GJ, van den Bergh Weerman MA, Kasper M, Heijmans J, Hardwick JC, Verspaget HW, Hommes DW, Toftgard R, Hahn H, van den Brink GR. Hedgehog signalling stimulates precursor cell accumulation and impairs epithelial maturation in the murine oesophagus. Gut 2013;62:348-57.

29. Clemons NJ, Wang DH, Croagh D, Tikoo A, Fennell CM, Murone C, Scott AM, Watkins DN, Phillips WA. Sox9 drives columnar differentiation of esophageal squamous epithelium: a possible role in the pathogenesis of Barrett's esophagus. Am J Physiol Gastrointest Liver Physiol 2012;303:G1335-46.

30. Quante M, Bhagat G, Abrams JA, Marache F, Good P, Lee MD, Lee Y, Friedman R, Asfaha S, Dubeykovskaya Z, Mahmood U, Figueiredo JL, Kitajewski J, Shawber C, Lightdale CJ, Rustgi AK, Wang TC. Bile acid and inflammation activate gastric cardia stem cells in a mouse model of Barrett-like metaplasia. Cancer Cell 2012;21:36-51.

31. Palles C, Chegwidden L, Li X, Findlay JM, Farnham G, Castro Giner F, Peppelenbosch MP, Kovac M, Adams CL, Prenen H, Briggs S, Harrison R, Sanders S, Macdonald D, Haigh C, Tucker A, Love S, Nanji M, DeCaestecker J, Ferry D, Rathbone B, Hapeshi J, Barr H, Moayyedi P, Watson P, Zietek B, Maroo N, Gay L, Underwood T, Boulter L, McMurtry H, Monk D, Patel P, Ragunath K, Al Dulaimi D, Murray I, Koss K, Veitch A, Trudgill N, Nwokolo C, Rembacken B, Atherfold P, Green E, Ang Y, Kuipers EJ, Chow W, Paterson S, Kadri S, Beales I, Grimley C, Mullins P, Beckett C, Farrant M, Dixon A, Kelly S, Johnson M, Wajed S, Dhar A, Sawyer E, Roylance R, Onstad L, Gammon MD, Corley DA, Shaheen NJ, Bird NC, Hardie LJ, Reid BJ, Ye W, Liu G, Romero Y, Bernstein L, Wu AH, Casson AG, Fitzgerald R, Whiteman DC, Risch HA, Levine DM, Vaughan TL, Verhaar AP, van den Brande J, Toxopeus EL, Spaander MC, Wijnhoven BP, van der Laan LJ, Krishnadath K, Wijmenga C, Trynka G, McManus R, Reynolds JV, O'Sullivan J, MacMathuna P, McGarrigle SA, Kelleher D, Vermeire S, Cleynen I, Bisschops R, Tomlinson I, Jankowski J. Polymorphisms near TBX5 and GDF7 are associated with increased risk for Barrett's esophagus. Gastroenterology 2015;148:367-78.

32. Su Z, Gay LJ, Strange A, Palles C, Band G, Whiteman DC, Lescai F, Langford C, Nanji M, Edkins S, van der Winkel A, Levine D, Sasieni P, Bellenguez C, Howarth K, Freeman C, Trudgill N, Tucker AT, Pirinen M, Peppelenbosch MP, van der Laan LJ, Kuipers EJ, Drenth JP, Peters WH, Reynolds JV, Kelleher DP, McManus R, Grabsch H, Prenen H, Bisschops R, Krishnadath K, Siersema PD, van Baal JW, Middleton M, Petty R, Gillies R, Burch N, Bhandari P, Paterson S, Edwards C, Penman I, Vaidya K, Ang Y, Murray I, Patel P, Ye W, Mullins P, Wu AH, Bird NC, Dallal H, Shaheen NJ, Murray LJ, Koss K, Bernstein L, Romero Y, Hardie LJ, Zhang R, Winter H, Corley DA, Panter S, Risch HA, Reid BJ, Sargeant I, Gammon MD, Smart H, Dhar A, McMurtry H, Ali H, Liu G, Casson AG, Chow WH, Rutter M, Tawil A,
Morris D, Nwokolo C, Isaacs P, Rodgers C, Ragunath K, MacDonald C, Haigh C, Monk D, Davies G, Wajed S, Johnston D, Gibbons M, Cullen S, Church N, Langley R, Griffin M, Alderson D, Deloukas P, Hunt SE, Gray E, Dronov S, Potter SC, Tashakkori-Ghanbaria A, Anderson M, Brooks C, Blackwell JM, Bramon E, Brown MA, Casas JP, Corvin A, Duncanson A, Markus HS, Mathew CG, Palmer CN, Plomin R, Rautanen A, Sawcer SJ, Trembath RC, Viswanathan AC, Wood N, Trynka G, Wijmenga C, Cazier JB, Atherfold P, Nicholson AM, Gellatly NL, Glancy D, Cooper SC, Cunningham D, Lind T, Hapeshi J, Ferry D, Rathbone B, Brown J, Love S, Attwood S, MacGregor S, Watson P, Sanders S, Ek W, Harrison RF, Moayyedi P, de Caestecker J, Barr H, Stupka E, Vaughan TL, Peltonen L, Spencer CC, Tomlinson I, Donnelly P, Jankowski JA, Esophageal Adenocarcinoma Genetics C, Wellcome Trust Case Control C. Common variants at the MHC locus and at chromosome 16q24.1 predispose to Barrett's esophagus. Nat Genet 2012;44:1131-6.

33. Martin V, Shaw-Smith C. Review of genetic factors in intestinal malrotation. Pediatr Surg Int 2010;26:769-81.

34. Levine DM, Ek WE, Zhang R, Liu X, Onstad L, Sather C, Lao-Sirieix P, Gammon MD, Corley DA, Shaheen NJ, Bird NC, Hardie LJ, Murray LJ, Reid BJ, Chow WH, Risch HA, Nyren O, Ye W, Liu G, Romero Y, Bernstein L, Wu AH, Casson AG, Chanock SJ, Harrington P, Caldas I, Debiram-Beecham I, Caldas C, Hayward NK, Pharoah PD, Fitzgerald RC, Macgregor S, Whiteman DC, Vaughan TL. A genome-wide association study identifies new susceptibility loci for esophageal adenocarcinoma and Barrett's esophagus. Nat Genet 2013;45:1487-93.

35. Gu Y, Lin S, Li JL, Nakagawa H, Chen Z, Jin B, Tian L, Ucar DA, Shen H, Lu J, Hochwald SN, Kaye FJ, Wu L. Altered LKB1/CREB-regulated transcription co-activator (CRTC) signaling axis promotes esophageal cancer cell migration and invasion. Oncogene 2012;31:469-79.

36. Woo J, Miletich I, Kim BM, Sharpe PT, Shivdasani RA. Barx1-mediated inhibition of Wnt signaling in the mouse thoracic foregut controls tracheo-esophageal septation and epithelial differentiation. PLoS One 2011;6:E22493.

37. Miletich I, Buchner G, Sharpe PT. Barx1 and evolutionary changes in feeding. $J$ Anat 2005;207:619-22.

38. Logan CY, Nusse R. The Wnt signaling pathway in development and disease. Аnпu Rev Cell Dev Biol 2004;20:781-810.

39. Yamamoto $S$, Nakase $H$, Matsuura $M$, Honzawa $Y$, Matsumura K, Uza N, Yamaguchi Y, Mizoguchi E, Chiba T. Heparan sulfate on intestinal epithelial cells plays a critical role in intestinal crypt homeostasis via Wnt/beta-catenin signaling. Am J Physiol Gastrointest Liver Physiol 2013;305:G241-9.

40. Niehrs C. The complex world of WNT receptor signalling. Nat Rev Mol Cell Biol 2012;13:767-79.

41. Blache P, van de Wetering M, Duluc I, Domon C, Berta P, Freund JN, Clevers H, Jay P. SOX9 is an intestine crypt transcription factor, is regulated by the Wnt pathway, and represses the CDX2 and MUC2 genes. J Cell Biol 2004; 166:37-47.

42. Ogaki S, Shiraki N, Kume K, Kume S. Wnt and Notch signals guide embryonic stem cell differentiation into the intestinal lineages. Stem Cells 2013;31:1086-96.

43. Fortini ME. Notch signaling: the core pathway and its posttranslational regulation. Dev Cell 2009;16:633-47.

44. Galipeau PC, Li X, Blount PL, Maley CC, Sanchez CA, Odze RD, Ayub K, Rabinovitch PS, Vaughan TL, Reid BJ. NSAIDs modulate CDKN2A, TP53, and DNA content risk for progression to esophageal adenocarcinoma. PLoS Med 2007;4:E67. 
45. Barrett MT, Galipeau PC, Sanchez CA, Emond MJ, Reid BJ. Determination of the frequency of loss of heterozygosity in esophageal adenocarcinoma by cell sorting, whole genome amplification and microsatellite polymorphisms. Oncogene 1996;12:1873-8

46. Dunn J, Garde J, Dolan K, Gosney JR, Sutton R, Meltzer SJ, Field JK. Multiple target sites of allelic imbalance on chromosome 17 in Barrett's oesophageal cancer. Oncogene 1999;18:987-93.

47. Skacel M, Petras RE, Rybicki LA, Gramlich TL, Richter JE, Falk GW, Goldblum JR. p53 expression in low grade dysplasia in Barrett's esophagus: correlation with interobserver agreement and disease progression. Am J Gastroenterol 2002;97:2508-13.

48. Chung SM, Kao J, Hyjek E, Chen YT. p53 in esophageal adenocarcinoma: a critical reassessment of mutation frequency and identification of 72Arg as the dominant allele. Int J Oncol 2007;31:1351-5

49. Mokrowiecka A, Wierzchniewska-Lawska A, Smolarz B, Romanowicz-Makowska H, Malecka-Panas E. p16 gene mutations in Barrett's esophagus in gastric metaplasia-intestinal metaplasia-dysplasia-adenocarcinoma sequence. Adv Med Sci 2012;57:71-6.

50. Hong J, Resnick M, Behar J, Wang LJ, Wands J, DeLellis RA, Souza RF, Spechler SJ, Cao W. Acid-induced p16 hypermethylation contributes to development of esophageal adenocarcinoma via activation of NADPH oxidase NOX5-S. Am J Physiol Gastrointest Liver Physiol 2010;299:G697-706.

51. Wang JS, Guo M, Montgomery EA, Thompson RE, Cosby H, Hicks L, Wang S, Herman JG, Canto MI. DNA promoter hypermethylation of $\mathrm{p} 16$ and APC predicts neoplastic progression in Barrett's esophagus. Am J Gastroenterol 2009;104:2153-60.

52. Weaver JM, Ross-Innes CS, Shannon N, Lynch AG, Forshew T, Barbera M, Murtaza M, Ong CA, Lao-Sirieix P, Dunning MJ, Smith L, Smith ML, Anderson CL, Carvalho B, O'Donovan M, Underwood TJ, May AP, Grehan N, Hardwick R, Davies J, Oloumi A, Aparicio S, Caldas C, Eldridge MD, Edwards PA, Rosenfeld N, Tavare S, Fitzgerald RC, Consortium O. Ordering of mutations in preinvasive disease stages of esophageal carcinogenesis. Nat Genet 2014;46:837-43.

53. Streppel MM, Lata S, DelaBastide M, Montgomery EA, Wang JS, Canto MI, Macgregor-Das AM, Pai S, Morsink FH, Offerhaus GJ, Antoniou E, Maitra A, McCombie WR. Next-generation sequencing of endoscopic biopsies identifies ARID1A as a tumor-suppressor gene in Barrett's esophagus. Oncogene 2014;33:347-57.

54. Zang ZJ, Cutcutache I, Poon SL, Zhang SL, McPherson JR, Tao J, Rajasegaran V, Heng HL, Deng N, Gan A, Lim KH, Ong CK, Huang D, Chin SY, Tan IB, Ng CC, Yu W, Wu Y, Lee M, Wu J, Poh D, Wan WK, Rha SY, So J, Salto-Tellez M, Yeoh KG, Wong WK, Zhu YJ, Futreal PA, Pang B, Ruan Y, Hillmer AM, Bertrand D, Nagarajan N, Rozen S, Teh BT, Tan P. Exome sequencing of gastric adenocarcinoma identifies recurrent somatic mutations in cell adhesion and chromatin remodeling genes. Nat Genet 2012;44:570-4.

55. Wiegand KC, Sy K, Kalloger SE, Li-Chang H, Woods R, Kumar A, Streutker CJ, Hafezi-Bakhtiari S, Zhou C, Lim HJ, Huntsman DG, Clarke B, Schaeffer DF. ARID1A/BAF250a as a prognostic marker for gastric carcinoma: a study of 2 cohorts. Hum Pathol 2014;45:1258-68.

56. Dulak AM, Stojanov P, Peng S, Lawrence MS, Fox C, Stewart C, Bandla S, Imamura Y, Schumacher SE, Shefler E, McKenna A, Carter SL, Cibulskis K, Sivachenko A, Saksena G, Voet D, Ramos AH, Auclair D, Thompson K,
Sougnez C, Onofrio RC, Guiducci C, Beroukhim R, Zhou Z, Lin L, Lin J, Reddy R, Chang A, Landrenau R, Pennathur A, Ogino S, Luketich JD, Golub TR, Gabriel SB, Lander ES, Beer DG, Godfrey TE, Getz G, Bass AJ. Exome and whole-genome sequencing of esophageal adenocarcinoma identifies recurrent driver events and mutational complexity. Nat Genet 2013;45:478-86.

57. Jarzynka MJ, Hu B, Hui KM, Bar-Joseph I, Gu W, Hirose T, Haney LB, Ravichandran KS, Nishikawa R, Cheng SY. ELMO1 and Dock180, a bipartite Rac1 guanine nucleotide exchange factor, promote human glioma cell invasion. Cancer Res 2007;67:7203-11.

58. Nones K, Waddell N, Wayte N, Patch AM, Bailey P, Newell F, Holmes O, Fink JL, Quinn MC, Tang YH, Lampe G, Quek K, Loffler KA, Manning S, Idrisoglu S, Miller D, Xu Q, Waddell N, Wilson PJ, Bruxner TJ, Christ AN, Harliwong I, Nourse C, Nourbakhsh E, Anderson M, Kazakoff S, Leonard C, Wood S, Simpson PT, Reid LE, Krause L, Hussey DJ, Watson DI, Lord RV, Nancarrow D, Phillips WA, Gotley D, Smithers BM, Whiteman DC, Hayward NK, Campbell PJ, Pearson JV, Grimmond SM, Barbour AP. Genomic catastrophes frequently arise in esophageal adenocarcinoma and drive tumorigenesis. Nat Commun 2014;5:5224.

59. Dvorak K, Payne CM, Chavarria M, Ramsey L, Dvorakova B, Bernstein H, Holubec H, Sampliner RE, Guy N, Condon A, Bernstein C, Green SB, Prasad A, Garewal HS. Bile acids in combination with low $\mathrm{pH}$ induce oxidative stress and oxidative DNA damage: relevance to the pathogenesis of Barrett's oesophagus. Gut 2007;56:763-71.

60. Satou K, Hori M, Kawai K, Kasai H, Harashima H, Kamiya H. Involvement of specialized DNA polymerases in mutagenesis by 8-hydroxy-dGTP in human cells. DNA Repair (Amst) 2009;8:637-42.

61. Xu E, Gu J, Hawk ET, Wang KK, Lai M, Huang M, Ajani $\mathrm{J}, \mathrm{Wu} \mathrm{X}$. Genome-wide methylation analysis shows similar patterns in Barrett's esophagus and esophageal adenocarcinoma. Carcinogenesis 2013;34:2750-6.

62. Alvarez H, Opalinska J, Zhou L, Sohal D, Fazzari MJ, Yu Y, Montagna C, Montgomery EA, Canto M, Dunbar KB, Wang J, Roa JC, Mo Y, Bhagat T, Ramesh KH, Cannizzaro L, Mollenhauer J, Thompson RF, Suzuki M, Meltzer SJ, Melnick A, Greally JM, Maitra A, Verma A. Widespread hypomethylation occurs early and synergizes with gene amplification during esophageal carcinogenesis. PLoS Genet 2011;7:E1001356.

63. Alvi MA, Liu X, O’Donovan M, Newton R, Wernisch L, Shannon NB, Shariff K, di Pietro M, Bergman JJ, Ragunath K, Fitzgerald RC. DNA methylation as an adjunct to histopathology to detect prevalent, inconspicuous dysplasia and early-stage neoplasia in Barrett's esophagus. Clin Cancer Res 2013;19:878-88.

64. Kaz AM, Grady WM, Stachler MD, Bass AJ. Genetic and epigenetic alterations in barrett's esophagus and esophageal adenocarcinoma. Gastroenterol Clin North Am 2015;44:473-89.

65. Eads CA, Lord RV, Kurumboor SK, Wickramasinghe K, Skinner ML, Long TI, Peters JH, DeMeester TR, Danenberg KD, Danenberg PV, Laird PW, Skinner KA. Fields of aberrant $\mathrm{CpG}$ island hypermethylation in Barrett's esophagus and associated adenocarcinoma. Cancer Res 2000;60:5021-6.

66. Wong DJ, Paulson TG, Prevo LJ, Galipeau PC, Longton G, Blount PL, Reid BJ. p16(INK4a) lesions are common, early abnormalities that undergo clonal expansion in Barrett's metaplastic epithelium. Cancer Res 2001;61:8284-9. 
67. Brock MV, Gou M, Akiyama Y, Muller A, Wu TT, Montgomery E, Deasel M, Germonpre P, Rubinson L, Heitmiller RF, Yang SC, Forastiere AA, Baylin SB, Herman JG. Prognostic importance of promoter hypermethylation of multiple genes in esophageal adenocarcinoma. Clin Cancer Res 2003;9:2912-9.

68. Sarbia M, Geddert H, Klump B, Kiel S, Iskender E, Gabbert HE. Hypermethylation of tumor suppressor genes (p16INK4A, p14ARF and APC) in adenocarcinomas of the upper gastrointestinal tract. Int $J$ Cancer 2004;111:224-8.

69. Smith CM, Watson DI, Michael MZ, Hussey DJ. MicroRNAs, development of Barrett's esophagus, and progression to esophageal adenocarcinoma. World $J$ Gastroenterol 2010;16:531-7.

70. Wijnhoven BP, Hussey DJ, Watson DI, Tsykin A, Smith CM, Michael MZ, South Australian Oesophageal Research G. MicroRNA profiling of Barrett's oesophagus and oesophageal adenocarcinoma. Br J Surg 2010;97:853-61.
71. Mees ST, Mardin WA, Wendel C, Baeumer N, Willscher E, Senninger N, Schleicher C, Colombo-Benkmann M, Haier J. EP300-a miRNA-regulated metastasis suppressor gene in ductal adenocarcinomas of the pancreas. Int $J$ Cancer 2010;126:114-24.

72. Suzuki HI, Yamagata K, Sugimoto K, Iwamoto T, Kato S, Miyazono K. Modulation of microRNA processing by $\mathrm{p} 53$. Nature 2009;460:529-33.

73. Chen X, Guo X, Zhang H, Xiang Y, Chen J, Yin Y, Cai X, Wang K, Wang G, Ba Y, Zhu L, Wang J, Yang R, Zhang Y, Ren Z, Zen K, Zhang J, Zhang CY. Role of miR-143 targeting KRAS in colorectal tumorigenesis. Oncogene 2009;28:1385-92.

74. Leidner RS, Ravi L, Leahy P, Chen Y, Bednarchik B, Streppel M, Canto M, Wang JS, Maitra A, Willis J, Markowitz SD, Barnholtz-Sloan J, Adams MD, Chak A, Guda K. The microRNAs, MiR-31 and MiR-375, as candidate markers in Barrett's esophageal carcinogenesis. Genes Chromosomes Cancer 2012;51:473-9. 